\author{
ЛИДИЈА Р. ТОМИК* \\ Универзитет Црне Горе, Никшић \\ Филолошки факултет
}

\title{
ПОЕТИКА СИМБОЛА У РОМАНУ ДЕОБЕ ДОБРИЦЕ ЋОСИЋА
}

\begin{abstract}
Рад обухвата поетичку структуру Ћосићевих симбола у односу на мотиве рата, револуције и контрареволуције. Од романа Далеко је сунще и наслова свих Ћосићевих романа, симболизација тема рата, коријена и диоба, у теми политичких идеологија, друштвених збивања и судбина јунака, тиче се историјске и психолошке перспективе ликова у теми српског народа, с универзалном перспективом трагичних збивања. Роман Деобе, у три књиге, има поетску структуру егзистенцијалног романа, са симболичком експресијом људских подјела.
\end{abstract}

Кључне ријечи: рат, диобе, идеологија, контрареволуција, четници, реалистичка мотивација, психолошка мотивација, симбол, интертекстуалност.

Роман Деобе Добрице Ћосића припада типу историјских романа, али је историјски контекст ратне тематике у функцији поетског начина приповиједања. Класични облик историјског романа замијењен је модерном структуром егзистенцијалних тема којима је оквир вријеме рата, а тежиште идеолошки и политички условљена подјела на четнике и партизане. Послије романа Далеко је сунще, с фокусом приповиједања на идеолошки ригидну одлуку партизанског вођства, и романа Корени, с модерно схваћеним немирима српског човјека, на размеђи патријархалног и новог доба, роман Деобе је на прекретници Ћосићевог интересовања за непознату страну историје и особине контрареволуције, којој Ћосић, као учесник рата, није припадао. Пред читаоцима је роман о тајновитој судбини четника, односно о виђењу четника и четничког покрета изнутра, из перспективе свједока догађаја и људских судбина.

Аутор романа Деобе најближи је наратору који приповиједа из угла заинтересованог приповједача. Синхроном тачком гледишта открива живот ликова из више перспектива. Ауторска позиција приповиједања је доминантна утолико више што се избор књижевних облика - дневника,

*lidijat@ac.me 
записа, писама, извјештаја, у смјењивању с формом монолога, дијалога, доживљених говора, доживљава као најобухватнији материјал и извор литерарних сазнања, паралела, митских архетипа и симбола, какав је у архитектоници двије војске, два знака на капама, двије стране истог поријекла и идентитета. Симбол села, цркве, бријеста, неба, земље, сунца, ливаде, нема у овом роману дескриптивну функцију, већ значењску, са семантичким одредницама припадности, страдања и спасења. Симболи рата блиски су симболима гротескне гозбе и пораза, било да је ријеч о теми жртве, било о теми пораза.

Писање романа Деобе пратило је и писање Дневника о Деобама. Дневник није објављен, осим његови дјелови, у најновијем издању романа Деобе (Ћосић 2017б). Искуство писања условило је дијалог с процесом стварања, што је још један разлог да вјерујемо да је Ћосић роман писао у постмодернистичкој енергији повратка традицији, њеним устаљеним и канонским одређењима. Ћосић се окреће теми четништва да би у покрету контрареволуције вредновао антрополошка и психолошка одредишта једне појаве пред питањем како је описати, одредити, насликати, а одговорити истини о тајни која више говори о размјерама човјекових искушења него о самом покрету. Он се открива у тексту, у особинама ликова и статусу „ьихове стварне судбине” (Ћосић 1977 [3]: 9). Роман оспољава тему рата и контрареволуције као систем драматичних суштина, са смислом приповједачки „свирепе, луксузне, несрећничке игре, којој је неизвесност и вредност и казна" (1977 [3]: 9). Само приповиједање, ауторовом игром с могућностима текста, постаје прича за себе, отворена структура с романескном слојевитошћу, видљивом чином приповиједања. Због тога, мисао Добрице Ћосића да је роман „био органски везан

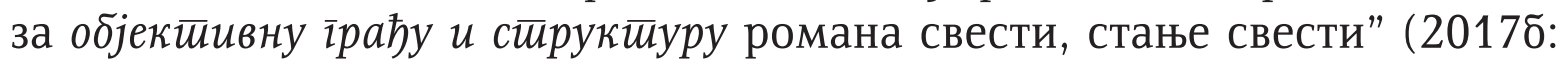
833), указује да је ријеч о тексту вишезначне предметности, с асоцијативним токовима приповиједања, које се схвата као „почетак краја мога ослобађања и ослобођења, књиге коју морам да завршим, коју никада стварно нећу завршити [...]" (1977 [3]: 10). Роман Деобе, тим начином, из реалистичког одређења идеолошких подјела, ушао је у старозавјетну тему и причу о Авраму и Исаку, Каину и Авељу, односно у вертикалу српске историје, од Тихомира и Стефана Немањића и старословенске традиције сукоба до историје у причи о Карађорђу и Обреновићима, у којој се наставља судбина прогона и смрти („Марш, очеви. Синови, у мајчину", 1977 [2]: 285).

Ауторов дијалог с традицијом у роману почиње заточењем народа у цркви, а завршава се трагичком кривицом синоубиства. Књижевни оквир трагичних збивања у роману Деобе ослања се на симболику ножа, на оштрицу етике и политике, на границе између оних који убијају и убијених, на визију смрти и нестајања, изнад којих се развија мисао о 
злу. Запитаност над феноменима зла искушава однос историјске и поетске истине. Ћосић је у „Дневнику Деоба”, слиједећи потребу да забиљежи тренутке писања романа, рекао да хоће „да говори[м] о тој ужасној снази човековој да буде злочинац чим му се прилика укаже, са циљем да деморалише[м] ту снагу и опомене[м] људе на обавезу човечности, доброте, одговорности за живот" (2017б: 828). Ћосић вјерује да су тематска упоришта његовог романа у опомени, у животним својствима која могу да побуде „стварање моралне свести, храбрости, верности, поштења" (1977 [2]: 296). Окренутост приповиједања „психологији четништва" или драми и „душевним ужасима” јунака говори да писца не опсједају „идеологије” и „политички мотиви”, већ „агонија једног менталитета”, истина „једне људске немоћи", искушења времена, која су симболички повезана с контрастима промашених идеала и потресних отрежњења. Ћосић тражи коријене зла („Влада је све упропастила. Твој Слободан Јовановић, твоји политичари, где је генерал Симовић", 1977 [3]: 18), идући за статусом и стањем ликова у више токова индивидуалне, породичне и друштвене стварности пада („[...] политика је игра у којој сви желе да добију, и том игром нико се не бави због поштења, већ ради интереса. Да се спасу колоније, Русима је жртвована Европа", 1977 [3]: 19).

Мисао писца да свједочи „о контрареволуцији у име хуманизма и прогреса" (Ћосић 2017б: 829) ослања се на њене „узроке” и „последице”. Ћосић поистовјећује роман с функцијом „открића” ликова, њихових заноса и неспоразума, са стварањем иконографски разуђеног простора ликова, различитих ситуација и контраста. Он је романом Деобе дао ликове војника и ратника, ликове сељака, везаних за кућу и земљу, ликове партизана, комуниста, везаних за револуцију, ликове демократа и интелектуалаца, политичара, народних првака, свештеника, ликове различите социјалне припадности и идеолошког опредјељења. Ћосић говори о историјским перспективама четничког и партизанског покрета, о токовима политичких идеја („Ви политичари криви сте за све, ви сте замесили ову говнарију”, 1977 [2]: 21), о судбини народа („Сами против свих. То је наша судбина", 1977 [2]: 31). Аутор изриче отпор према уништењу („[...] реч је буквално о физичкој егзистенцији једног народа, о стотини хиљада породица, о тоталном уништењу највећег националног покрета у Европи", 1977 [3]: 32), као и самоуништењу, доводећи у везу политичке и личне неспоразуме ликова. Ћосићеви јунаци доживљавају апсурд политичког времена („Ја сам поступао и храбро и поштено и све сам жртвовао својој идеји, а данас сам за свет и издајник и покварењак", 1977 [3]: 44) и сасвим индивидуалне диобе, драматичне сукобе између очева, синова, породичних традиција, политичких мишљења, увјерења, једном ријечју, осећања националних питања и сасвим супротних окви- 
ра политичких дужности, на штету егзистенцијалне оправданости трагичних поступака и одлука.

Тематска усредсређеност на живот ликова у односу на одреднице политичког убјеђења и његове сврхе, условила је „велико окупљање” најупечатљивијих симбола „црвене звезде са српом и чекићем” и „шубаpe” с „краљевским грбом и мртвачком главом”. Иконичност слика проширена је улогом Њемаца и улогом Енглеза у судбини српског народа. Приповиједање ликова пред искушењима отпора и борбе индивидуализује свијет јунака, ликове мајора Косте Цветића, његовог сина Бранка, који одлази у партизане, Бате Павловића, Уроша Бабовића, чији син страда због очеве догматске свијести или лудила да „кривицу” сина казни његовим погубљењем. Апсурд искључивости даје овом роману драмску форму, по чиновима драмски наглашених размишљања и откривања јунака. Симболи пада у функцији су друге крајности - логике да се „смрћу и поразом [...] победи и спасе национална част и достојанство”. Сурови реализам прелази у романтични занос, а унутрашња патња - у конфликт ставова, мишљења и одлука, увијек психолошки подстакнутих моралним питањима, идеолошким противницима, нестандардним наравима и карактерима. Све постаје врло сложено јер се у националној традицији и симболизацији земље, краља и отаџбине, налази психолошки продубљен мотив издаје, у два правца. Једним резултира мотив неслоге („то је српска трагедија”, 1977 [3]: 125), а другим - „саботерство и деморализација" (1977 [3]: 144). Симболи части преплићу се са симболима изневјереног очекивања, извјесност борбе - с поданичком и користољубивом улогом ликова. Дачићи и Катићи мијењају улоге, потомци газда прелазе на другу страну, а слуге се сударају са етиком вјерности и обичајном традицијом међусобних односа. Сукоб унутар четничког покрета („[...] поклали би се овде [...]”, 1977 [3]: 155) говори о поразу, о историјском промашају, о националној и људској деградацији историјског замаха да остану вјерни идеји српске националне традиције. Том идеалу супротстављен је агон међусобних ликвидација, са симболима крвавих тројки, убијања без кривице којима ликови не знају узрок. Не зна их ни аутор романа, као ни лик који свог саговорника упућује на Добрицу Ћосића („љубиша, шта си ти крив?” / „Питајте Добрицу Ћосића. Он треба да зна шта сам", 1977 [3]: 187). А писац Добрица Ћосић своју мисао о злу и његовом дејству у историјским трансформацијама везује за текст, за свијет ликова у хаосу времена и за јунаке, као свештеник Гаврило, који постаје војник Добривоје, у одсудним исходима живота и смрти.

Тема њемачке окупације је подтема ауторове визије ратних сукоба. Њемци, као окупатор, и партизани, као друга страна отпора, имају подређен статус у приповједачевој намјери да визуализује живот четника и потражи одговор на недоумице о размјерама трагичних неспоразума. 
Полазећи од симболике људског спасења и симбола цркве, на почетку романа, и терора над заробљеним народом, приповједач укршта искуства ликова, симболе пада и побуне. Говор разочарања и молитве, гњева и молбе („Црква се прели храпавим подераним јауцима, крвавим и другим комадима гласа, оног последњег, ишчупаног из костију", Ћосић 1977 [1]: 92) конкретизује простор људске немоћи. Употреба изражајних глагола: „наваљују”, „ударају”, „гризу”, „газе се”, „цепају”, метафорички интензивирају апокалиптичне сцене зла, под којим, у антагонизму различитости, и у историјској перспективи супротстављених ставова, приповједач тематизује прошлост, сјећања на трагику Првог свјетског рата и 1914. годину, у истом, поновљеном искуству патње. Притом, теми заточења супротставља тему природе, космичкој хармонији - тему страдања. Вертикала људске и небеске стварности сједињена је темом неба и земље, Бога и човјека, патријархалног живота и комунистичког доба, прошлости и садашњег тренутка. Интелектуалне, политичке и књижевне теме отпора и побуне („О, народе, је ли истина да смо баш сви пакао заслужили", 1977 [1]: 87) захватају људске могућности и трансформације, од снаге и издржљивости до слабости јунака и питања „шта још човек може" (1977 [1]: 112) у искуству пораза.

Реалистичка мотивација приповиједања прелази у натуралистичку реалност ликова, у модерно схваћен поредак зла. Аутор документује и инкорпорира слике зла, рекапитулира и аргументује искуства зла, записана још у славеносрпској ери глади и пустоши („Крв свих разлика”, тим начином, прелази у „крв потпуне једнакости у свему”, Ћосић 1977 [1]: 117), све до новијег времена и несреће отуђења и подјела. Зло постојања синхронизује се драмом човјека под ћудима времена и императива постојања („Постоје болови и жеђ и зато жеља да се живи. Мора”, 1977 [1]: 118).

Ћосићев приповједач трага за почецима подјела у причи о Србији, Њемачкој и Русији, у дисперзији и расколима патријархалне и модерне традиције. Аутор иде за питањем „шта се догодило са српским народом, његовим патриотизмом, слободарским традицијама и поносом [...]" (Ћосић 1977 [1]: 139), за антагонизмима села и града, етичким константама и њиховим изневјереним вриједностима. Романескни простор везаног, али и искиданог говора, поетски разломљеног и интензивираног стањем јунака или приповједача, обједињава и емоционално, и контемплативно казивање, говор подсвијести и искуство ликова. Тим начином, аутор жанровски шири поетски хоризонт романа и различитим формама приповиједања динамизује искуство трагичних диоба. То није свједочење оног што је било, већ суочавање с оним што јесте у искуству писања. Стања великог броја ликова варирају токове људских судбина, због чега 
овај роман пружа широк хоризонт ликова, породица, њихових односа и сукоба, неразумијевања и конфликата. У теми политичких увјерења, мисли и дилема, мишљења и реакција ликова, роман има особине модерно организоване прозе. У њеном спољашњем току одвијају се догађаји и живот ликова, а у унутрашњем - инверзије и парадокси индивидуалних и општих питања словенске и српске културе, српске цивилизације и културе Запада. Аутор има у виду тип „балканског политичког морала” у историјским приликама, али и историју у видокругу подјела на комунисте и четнике, који напуштањем или одбраном традиције граниче два тока историје. У оба одређења, фикција политичких разлика оспољава драму ликова, са супротстављеним осјећањима националне свијести и интернационалног заноса. С психолошки декомпонованом одредљивошћу историјске прошлости, развија се поступак интроспекције и ретроспекције, која укршта мисао револуције и контрареволуције. Роман Деобе је, стога, поетски измијенио перспективу историјског романа. Он је, отуда, и поема, и епопеја, и сага, ратних и политичких прилика, ликова, њихових заноса и заблуда, политичких одлука и емоционалних стања. Ријеч је о неколико нивоа романескне приче, о фабули која онеобичава живот јунака између моралне доследности и људске слабости. Имајући у виду став да „вечно истинита филозофија изражава наше урођено осећање да у вези с људским бићима и материјалним светом постоји и нешто више од онога што се очима може видети" (Армстронг 2005: 15), Ћосић отвара поетски видокруг вишег реда, саздан унутар бића и изван њега, у судару са собом и другим.

Ауторова мисао о четницима тицала се могућности упознавања с непознатим, с истином вриједности које су опредијелиле четнички покрет. С дискурзивном сликом модернистички схваћених стања побуне, бола, идеализма, идеја националне традиције, војничке части и немогућности четника да објективизују и испуне захтјеве времена, роман говори о трагичној кривици и раскораку ликова између оног што желе и оног што могу, на простору трагикомичних сурвавања у ништавило и узалудност. Приповједач, отуда, мозаички везује, у три књиге, мисао и поступке јунака, опредјељења и сумње, вјерност идеји и сумњу у идеју контрареволуције. Фикција јунака прелази у метафикцију ликова у паду, у невјерици, у очају, у кајању, у теми пропасти и нестајања.

Приповиједање с преплитањем прошлости и садашњег тренутка учинило је да ауторов „дијалог” с ликовима садржи објашњења, коментаре и информације, сагласне разумијевању егзистенцијалних тренутака и стања у ратом одређеном поретку. Приповиједање је окренуто унутрашњости бића, говору немира и психолошки напрегнутих ситуација ( Памћење је моја казна”, Ћосић 1977 [1]: 43). Искуства рата су, 
тако, искуства бола и смрти, везана за човјека, породицу, народ, а не искључиво за ликове четника, по одређењу њихове припадности. Ћосић има у виду распоне узвишеног и ниског у избору ликова партизана, у људској природи, у институционалном дјеловању и психолошкој мотивацији поступака. Сама подјела јунака на оне „који убијају” и на „оне који су убијени", с почетка романа, актуализује трагику људске угрожености у поетској симболизацији питања зашто уз „каме”, симбол смрти, иду „вратови за каме”. Тајна је у теми ножа, како је роман требало да се зове, у симболизованом злу које аутор везује за човјека самог.

Симболизација земље и ликова у „Николиној Србијици”, у Прерову, Трнави, Планини, чаршији, патријархалном наслеђу, грађанској традицији, садржи симболичне топониме винограда, шљивика, ријека, као мјеста „великих окупљања и деоба” (Ћосић 1977 [1]: 41). Визија Србије, између западне и источне културе, Европе и Русије, нуди још једну опречност - између демократије и сукоба, иманентних нараторовој свијести о антагонизмима и расколима.

Први дио романа носи наслов „Откриће” и значењски је у функцији ауторске дилеме „да ли онај који је четништво гледао само суженом зеницом за нишан” и „коме је савест била да буде противник” може „сада да буде сведок, судија” (Ћосић 1977 [1]: 44). Приповједна неизвјесност не нуди само тему четништва, већ тему опстанка, преживљавања и спасења, тему страха од зла, као и мисао да се историја понавља и да је прича о диобама, у ствари, прича о искуству људске и политичке разједињености, с једне, и божанске хармоније, која укључује поетски изнијансирану визију постојања, с друге стране.

Приповједач у роману актуализује теме политичке борбе с бруталношћу сурове јаве. Чини то приповиједањем људских стања, паралелизмима и крајностима људске муке и озарења. На тај начин укрштају се питања „ко је грешан”, „поштен”, „дужан”, ко невин или безгрешан, а ко крив и немилосрдан. Роман Деобе, тако, симболизује могућности егзистенције у структури прозног израза и семантици одговора на питања „шта још текст може”. То што је Ћосић тражио, одговорио је текстом, приповједном и доживљајном перспективом приповиједања, с особинама поетске, документарне и интертекстуалне реконструкције четничког покрета, више него партизанског, при чему се и један и други ток одвијају у теми српског народа. О њему читалац сазнаје и из извјештаја стране мисије, чиме се документује поетска истина извором друге врсте - документом који информише о мотивима војничке етике („војничка издржљивост и скромност”), али и о мотивима „класичног дивљаштва”, гостопримства, „пљачке” („краду из неког свог егзибиционизма [...]. Крађа је за њих једно сладострасно и чулно хазардирање", Ћосић 1977 [2]: 170). Тема патријархалности овој прози даје вид објективно предочене стварности, која исти- 
че култ заставе, као симбола државе и народа („Бригада има да падне за заставу”, 1977 [2]: 187), и етике у којој је „морал доследности најперфиднији изговор за свакојаке злочине" (1977 [2]: 201).

Приповједач вјерује да се систем вриједности диобама претворио у своју супротност („Кажи ми каква је то слобода и може ли бити слободе ако за њу отац убија свога сина”, Ћосић 1977 [2]: 222). „Људи нијесу достојни Христа", говори јеромонах Гаврило, поредећи их с Прометејем и јунацима Горког. Легенда, предање и прича повезују литературу и свијет ликова, тако да судбину српског сељака, војника и интелектуалца, у више приповједних линија, открива и дневник студента, и казивање универзитетског професора, и мисао мајора, команданта и генерала, потом српског домаћина, газде и слуге, свештеника и извршилаца тајних задатака. Приповиједање открива и успоставља синхрону и дијахрону раван садашњег тренутка и цитираних дјелова српске средњовјековне збиље. Симболична сугестија тог начина говори да су диобе стање а не изузетност, више традиција него изабрани идеолошки раскол. Он је нови моменат у историји људских слабости, неповјерења и мржње, односно сличност која се чита у специфичним карактеристикама људске „заразе, болести и лудила” (1977 [1]: 142).

Приповиједање деоба комбинацијом записа, у виду увученог текста од текста који исписује приповједач, и дневника који је штампан курзивом, навођењем имена ликова који говоре, у функцији је Ћосићевог отвореног дјела, из више углова. Тим начином, смјењује се мисао о кризи национализма с темом љубави према отаџбини, конзервативна мисао с либерално-демократским увјерењима. И ликови дијеле судбину диоба: Урош Бабовић је „традиционалист”, а Бата Павловић - „модерни пророк" (Ћосић 1977 [1]: 202), један догмата, а други опомена пред „монструозним патриотизмом" (1977 [2]: 203). Аутор у овој прози није судија, већ „свједок”, хистор који говори о злу и судбини земље и јунака пред симболима нације, интернационализације, диктатуре и ропства.

У симболичном речнику овог Ћосићевог романа издвајају се ријечи Србин, Српкиња, мати, отаџбина. Оне су ослонац националне традиције, херојске, Карађорђеве Србије, али и обреновићевске Србије. Диобе династија и српског народа говоре о судбини Срба и трагизму који се односи на дилеме између наслеђа парламентарне монархије и државе без Христове вјере и цркве. Диобе у роману, као и рат, узрокују велика искушења четника и партизана, али и „прочишћење човјечанства” (Ћосић 1977 [1]: 287). Диобе у роману говоре о „агонији машинске цивилизације”, о „краху епохе”, о улози великих сила у судбини српског народа. Роман Деобе симболизује драму бића, запитаност пред извјесношћу пораза (Урош Бабовић се пита: „Шта сам ја сада”, 1977 [1]: 337). 
У роману Деобе приповиједа се цјелина егзистенције, доба са сновима, идеалима, циљевима, али и с пропагандама, дезертерством, интересима, љубављу, мржњом, с облицима сказа у казивању Лазара Обичног и Љубише Дачића. Говор патње и страха, побуне и очаја („Еј Србијо, курвина мајко, копилачка мајко", Ћосић 1977 [1]: 381) садржи и говор лажи („Зашто лажу да ми нападамо Паланку? Хоће да запале Србију. За кога?”, 1977 [1]: 384), насиља, звјерства, клања, убијања, смрти („Рат, то је рат, опет рат, докле ћу, бем те, судбино", 1977 [1]: 414).

Кључна реченица Деоба је у тачки пресјека: „Како да те спасем, крвниче мој” (Ћосић 1977 [2]: 11), или како да се политичка доследност мјери немјерљивом одлуком о убиству сина („И Аврам је кренуо ножем на Исака", 1977 [2]: 125). Ћосићеве Деобе приповиједају трагику бића, кошмар, Јудино дјело пропадања, разур „српске баштине”, са симболима контраста - светих празника (Бадње вече) и крвавих обрачуна у њима. Роман Деобе симболизује вријеме супротности, од агитација партизанских летака, владиних извјештаја с окупиране територије, до говора моћи и великих слабости. Егзекуције и погубљења симболички реализују мотиви „мртвог дрозда”, „црне птице”, Адамовог бријеста („[...] и онај што је био ништа сад је све", 1977 [2]: 77). Ликови постају звијери, а звијер - створење с грозницом и бунцањем. Јунак Миле Савковић каже да „једнако мрзи[м] и четнике и комунисте” (1977 [2]: 144), а жена Бате Павловића види сличност Уроша Бабовића, „оног зеленаша, неандерталца", с ликом „сељачког Карамазова” (1977 [2]: 153).

Посебно мјесто у другој књизи романа Деобе дато је мотиву свадбе и симболу ножа, с антропоморфним својствима ликова унутар „несрећне игре” која тражи жртве („Черчил нас је жртвовао Стаљину. Бољшевизам ће сатрти Европу. Историја се понавља. Опет варвари руше Рим", Ћосић 1977 [3]: 17).

Трећа књига романа Деобе почиње поглављем чији је наслов симболичан - „Ропац”. У постмодернистичком духу, приповједачка позиција актуализује искуства стварања и искуство писања. Писање значи трагање, откривање, вредновање, с повратком на симболику отворене књиге и метафору људских диоба и разлика. Приповједни токови једног и другог оквира, четника и партизана, имају „живот свакодневице, пред којим су устукнули Лењин и Робеспјер". Ријеч је о реалности друге врсте, о мудрости која не дијели, већ спаја просторе илузија и идеала с животом по себи. Симбол диоба у тој семантичкој равни говори о трагици бића, о узалудном отпору пред силама зла. Коста Цветић на увреде Енглеза Џорџа узвраћа песницом, увријеђен оптужбама за издају. Урош Бабовић убија сина због осјећања дужности и остаје да тоне у земљу, заједно с кулом која пропада у земљу. Тим чином, трагика деоба добија 
апсурдни контекст и драмски врхунац у расулу душе, немиру и патњи, дакле у стањима од којих, сасвим симболично, јунак „тоне” као и кућа. Диобе не престају, оне се настављају и тамо гдје је контакт ликова прекинут - Адам Катић говори Урошу „како је Милош победио” (Ћосић 1977 [3]: 71).

Диобе се, у низу симболичних трансформација, тичу међусобних ратних околности, обрачуна, прогањања, убијања. Приповједач свједочи да тема „лазаровске жртве” спасава од осјећања пропасти, да се њом чува достојанство жртве. Коста Цветић пита „ко је већи Србин од мене. Ко више воли слободу од мене. Ко више мрзи Немце од мене [...]" (Ћосић 1977 [3]: 92), изричући трагични неспоразум у злу завјера, хапшења, прогона, једном ријечју, у злу парадокса, који и доследност Косте Цветића, носиоца Карађорђеве звијезде из Првог рата, доводе у сумњу. Деобе су роман с драматичним паноптикумом зла, трагичних мобилизација, кажњавања неистомишљеника, жртвовања угледнијих људи. Ликови овог романа су трагични јунаци, с деморалисаном свијешћу о својој улози у политичким процесима („У Лондону и Вашингтону одлучују о нашој судбини", 1977 [3]: 146). Контрареволуција је изгубила не зато што није била свјесна своје улоге, већ што није дисциплином духа и отпора успјела да отклони зло освете, мржње и покоља, односно понора људских недовољности и кривице. Ћосић у роману не доказује политичку страну контрареволуције, али се она, у својој пропасти, чита у романескној визији јунака, у тексту који конституише одговор писца, Добрице Ћосића, својим романом. Поражени човјек је фокус Ћосићевог романа, а текст о диобама - поетски и естетски плод симбола пролазности и сазнања да се тема диоба тиче људске егзистенције. У њој су ликови из живота и историје, литературе и традиције. У роману је мисао Драгише Васића о националној перспективи српског народа, што говори о томе да је Ћосић проучавао историјску истину и да је њом ширио хоризонт егзистенцијалне драме, означене књижевном симболиком и универзално схваћеном парадигмом Ћосићеве теме.

\section{ИЗВОРИ И ЛИТЕРАТУРА}

Armstrong, Karen. Kratka istorija mita, Beograd: Geopoetika, 2005. Št.

Ćosić, Dobrica. Deobe, 1-3. Romani Dobrice Ćosića. Rijeka: „Otokar Keršovani”, 1977. Št.

Ћосић, Добрица. Деобе, Београд: Laguna, 2017а. Шт.

Ћосић, Добрица. „Из Дневника Деоба”. Деобе. Београд: Laguna, 2017б: 829-836. Шт. 
Lidija R. Tomić

THE POETICS OF SYMBOLS IN DOBRICA ĆOSIĆ'S NOVEL DIVISIONS

\section{Summary}

The paper treats the poetic structure of Ćosić's symbols regarding the motifs of war, revolution and counterrevolution. Starting with the novel Far Away Is the Sun and the titles of all Ćosić's novels, the symbolisation of the topics of war, roots and divisions, in the topic of political ideologies, social upheavals and heroes' fates, concerns the historical and psychological perspective of characters within the topic of the Serbian people, with a universal perspective of tragic events. The three-volume novel Divisions has a poetic structure of the existentialist novel, with a symbolic expression of human divisions. 